\title{
Sociedad de riesgo: El incumplimiento de la Ley de Acceso a la Información por la Comisión Técnica Nacional de Bioseguridad (CTNBio) de Brasil
}

Nildete S. de Oliveira

Doctoranda en derecho por el Uniceub,

Brasilia, Brasil

\section{Resumen}

Este artículo hace un análisis sobre la falta de respeto a la Ley de Acceso a la Información por la Comisión Técnica Nacional de Bioseguridad (CTNBio). El artículo también reflexiona sobre los riesgos que existen en la sociedad contemporánea relacionadas con la (CTNBio y el derecho de los ciudadanos y de la sociedad de acceso a la información a partir de una perspectiva ambiental. La argumentación parte de la comprensión de los conceptos de riesgo, de sociedad de riesgo, de derecho a la información y de la norma creadora de la (CTNBio. Se toma como parámetro un estudio de caso relacionado con el tratamiento dado a la cuestión de riesgo ambiental y las informaciones proporcionadas por la Comisión Técnica (CTNBio). Se concluyó que la sociedad, además de tener el derecho, también necesita conocer el grado de riesgo al cual está siendo expuesta, así como sus consecuencias. Se sugiere como medida para lograr la solución del problema, la

Palabras clave:

sociedad de riesgo, Comisión Técnica Nacional de Bioseguridad (CTNBio), incumplimiento de la ley de acceso a la información 
creación inmediata del Sistema de Informaciones en Bioseguridad - SIB. Esto es para cumplir con la función de comunicar datos a la CTNBio que sean de interés para ese órgano y para la población como: sistematizar sus informes anuales con información clara que ayude al ciudadano a conocer los temas tratados; promover frecuentes audiencias públicas con el objetivo de permitir y fomentar el diálogo entre el gobierno y los electores y finalmente efectivizar el derecho de acceso a la información.

\section{Abstract}

This article analyzes the National Technical Commission on Biosafety (CTNBio) disrespect of the Access to Information Act. This article also reflects on the impending risks related to CTNBio which contemporary society faces, and on citizens' rights and access to information from an environmental perspective. The argument stems from the understanding of the concepts of risk, risk society, the right to information, and the institutionalization of CTNBio. As a parameter, we select a case study related to treatment of the issue of environmental risk and the information provided by the National Technical Commission on Biosafety (CтNBio). We conclude that society has the right to be informed and also needs to know the degree of risk to which we are exposed, as well as its consequences. As a measure to achieve the solution of the problem, we suggest the immediate establishment of the Biosafety Information System - SIB - to comply with the duties to communicate data of interest to the CTNBio and to the population by systematizing their annual reports, providing clear information that helps the citizen to know the issues addressed, holding public hearings with the aim of enabling and encouraging dialogue between the government and the voters and, ultimately, safeguarding the right of access to information.

\section{Keywords:}

society at risk, National Technical Commission on Biosafety (CTNBio), disregard of the law of access to information. 